\title{
PENGARUH SUSU KACANG KEDELAI (GLYCINE MAX (L.) MERR.) TERHADAP KUALITAS SPERMATOZOA TIKUS WISTAR (RATTUS NORVEGICUS)
}

\author{
${ }^{1}$ Valentine Madianung \\ ${ }^{2}$ Lusiana Satiawati \\ ${ }^{2}$ Lydia Tendean
}

\author{
1 Kandidat skripsi Fakultas Kedokteran Universitas Sam Ratulangi Manado \\ Bagian Biologi Fakultas Kedokteran Universitas Sam Ratulangi Manado \\ Email: ddhytamadianung@yahoo.co.id
}

\begin{abstract}
The effects of soy beans on spermatozoa still been a controversial thing. Soy is one of the source of the Fitoestrogen because the structure isoflavon of soy is similar with the structure of estrogen molecule, so it can confound the balancial of hormone. Soy also as a source of protein that rich of amino acid arginin. The study was carried out to find the effects of soy bean milk on spermatozoa qualities. This experimental study was conducted to nine wistar rats weighing from 200 to 250 grams. These nine wistar rats were divide into 3 groups. Consists of control group $(\mathrm{K})$ that did not gives the soy bean milk, the group $1\left(\mathrm{P}_{1}\right)$ that gives the soy bean milk with dose $500 \mathrm{mg} / \mathrm{kg} \mathrm{BB} /$ day and the group $2\left(\mathrm{P}_{2}\right)$ with dose $780 \mathrm{mg} / \mathrm{kg}$ $\mathrm{BB} /$ day. Treatment carried out for 60 days. As a result, there is an improvement in consentration and morphology of spermatozoa which are statistically significant $(p<0,05)$ in group $1\left(\mathrm{P}_{1}\right)$ and group $2\left(\mathrm{P}_{2}\right)$. Spermatozoa motility have a tendency to rise, but statistically meaningless $(p>0,05)$. Conclusion: The higher dose of soy bean milk may rise the concentration, morphology and motility of spermatozoa wistar rats.
\end{abstract}

Keywords: soy bean, soy bean milk, qualities of spermatozoa.

\begin{abstract}
Abstrak: Pengaruh kacang kedelai terhadap kualitas spermatozoa masih menimbulkan kontroversi. Kedelai merupakan salah satu sumber fitoestrogen karena struktur isoflavon kedelai mirip dengan struktur molekul estrogen sehingga dapat mengacaukan keseimbangan hormon. Kedelai juga sebagai sumber protein yang kaya akan asam amino arginin. Penelitian ini bertujuan untuk mengetahui efek dari susu kacang kedelai terhadap kualitas spermatozoa tikus wistar. Penelitian ini menggunakan 9 ekor wistar yang terbagi secara acak ke dalam 3 kelompok. Terdiri dari Kelompok kontrol yang tidak diberikan susu kacang kedelai, kelompok perlakuan $1\left(\mathrm{P}_{1}\right)$ yang diberi susu kacang kacang kedelai dengan dosis 500mg/kgBB/hari dan kelompok perlakuan $2\left(\mathrm{P}_{2}\right)$ dengan dosis $780 \mathrm{mg} / \mathrm{kgBB} / \mathrm{hari}$. Pemberian perlakuan berlangsung selama 60 hari. Hasil penelitian memperlihatkan peningkatan konsentrasi dan morfologi spermatozoa yang signifikan secara statistik $(p<0,05)$ antara kelompok perlakuan $1\left(\mathrm{P}_{1}\right)$ dan kelompok perlakuan $2\left(\mathrm{P}_{2}\right)$. Motilitas spermatozoa pada kelompok perlakuan $1\left(\mathrm{P}_{1}\right)$ dan kelompok perlakuan $2\left(\mathrm{P}_{2}\right)$ mempunyai kecenderungan meningkat, tetapi secara statistik tidak bermakna $(p>0,05)$. Simpulan: Makin tinggi dosis susu kacang kedelai yang diberikan, dapat meningkatkan konsentrasi, motilitas, dan morfologi spermatozoa tikus wistar.
\end{abstract}

Kata kunci: kacang kedelai, susu kacang kedelai, kualitas spermatozoa.

Infertilitas merupakan salah satu masalah yang dialami pasangan suami istri. Salah satu penyebab infertilitas berasal dari faktor pria akibat gangguan produksi sperma. 
Berdasarkan data infertilitas di dunia menurut WHO dilaporkan bahwa 8-12\% pasangan suami istri yang mengalami masalah infertilitas pada usia reproduktif dan sebanyak $25 \%$ dari pasangan suami istri tidak memiliki keturunan dalam waktu setahun pasca menikah. ${ }^{1}$ Saat ini diketahui faktor pria ataupun wanita mempunyai konstribusi yang sama. ${ }^{2}$

Penelitian terkini menyatakan bahwa adanya kemungkinan efek yang merugikan dari toksin lingkungan, seperti dari tumbuhan terhadap proses reproduksi. Salah satunya adalah fitoestrogen. Fitoestrogen merupakan suatu senyawa yang banyak ditemukan disekitar dan dapat mengacaukan keseimbangan sistem hormon binatang dan manusia. ${ }^{3-5}$ Kedelai merupakan salah satu sumber fitoestrogen karena struktur molekul isoflavon kedelai mirip dengan struktur molekul estrogen. ${ }^{2}$ Hal ini menyebabkan isoflavon kedelai dapat berikatan dengan Receptor estrogen (RE). Kandungan isoflavon pada kedelai berkisar 2-4 mg/g kedelai. ${ }^{6}$

Penelitian yang dilakukan oleh Committee on Toxicity of Chemicals in Food, Consumer Product and the Environment melaporkan bahwa pemberian suplemen isoflavon terhadap pria non vegetarian tidak mempengaruhi kadar estradiol, testosteron, LH, FSH, volume semen, jumlah sperma, motilitas dan morfologi sperma ataupun pada volume testis. $^{5,7}$ Penelitian yang dilakukan oleh Puspasari $^{8}$ ditemukan rerata morfologi spermatozoa abnormal paling rendah pada kelompk mencit yang tidak diberi ekstrak kedelai dan paling tinggi pada kelompok ekstrak kedelai 780mg/hari.

Penelitian sebelumnya menunjukkan adanya dua pernyataan yang berbeda mengenai pengaruh kacang kedelai terhadap kualitas spermatozoa. Hal ini membuat peneliti tertarik untuk melakukan penelitian lebih lanjut menggunakan susu kacang kedelai dengan dosis yang berbeda untuk melihat sejauh mana pengaruh kacang kedelai terhadap konsentrasi, morfologi, dan motilitas spermatozoa tikus wistar.

\section{METODE PENELITIAN}

Penelitian ini merupakan penelitian eksperimental dengan pendekatan post test only control group design, dilakukan pada periode November 2015 sampai Januari 2016 di Laboratorium Biologi Fakultas Kedokteran Universitas Sam Ratulangi, Manado. Penelitian ini menggunakan 9 ekor tikus wistar berumur 12-15 bulan dengan berat badan 200-250 gram. .

\section{Tahap Perlakuan}

Perlakuan pemberian susu kacang kedelai dilakukan setelah hewan percobaan mengalami aklimatisasi selama 1 minggu. Sebelum perlakuan dilakukan, hewan percobaan ditimbang terlebih dahulu untuk mengetahui berat badan awal. Setelah itu, dibagi menajdi 3 kelompok, masing-masing kelompok terdiri dari 3 ekor tikus wistar. Kelompok kontrol (K) tidak diberikan susu kacang kedelai, kelompok perlakuan $1\left(\mathrm{P}_{1}\right)$ diberi susu kacang dengan dosis 500mg/kgBB/hari dan kelompok perlakuan $2\left(\mathrm{P}_{2}\right)$ dengan dosis 780mg/kgBB/hari. Susu kacang kedelai diberikan melalui sonde lambung. Pemberian perlakuan selama 60 hari.

Pengambilan Sampel

Parameter yang diamati adalah konsentrasi, motilitas dan morfologi spermatozoa. Pada akhir perlakuan, hewan coba di terminasi dengan cara dilakukan dislokasi leher selanjutnya organ reproduksi berupa testis dan epididimis sampai duktus deferens diisolasi dan diperiksa.

\section{HASIL PENELITIAN}

Data yang didapatkan berasal dari 9 ekor tikus wistar berumur 12-15 bulan dengan berat 200-250 gram, Penelitian ini dilakukan selama 60 hari terhitung dari tanggal 6 November 2016 sampai 5 Januari 2016.

Pada Tabel 1. dapat dilihat terjadi perubahan rerata konsentrasi spermatozoa antara kelompok kontrol (K), kelompok perlakuan $1\left(\mathrm{P}_{1}\right)$ dan kelompok perlakuan 2 $\left(\mathrm{P}_{2}\right)$ yang menunjukkan adanya peningkatan. Diantara kelompok perlakuan, rerata konsentrasi kelompok perlakuan 2 
$\left(\mathrm{P}_{2}\right)$ lebih tinggi daripada rerata konsentrasi kelompok perlakuan $1\left(\mathrm{P}_{1}\right)$.

\section{Konsentrasi Spematozoa}

Tabel 1. Rerata Konsentrasi Spermatozoa

\begin{tabular}{cc}
\hline Kelompok & $\begin{array}{c}\text { Konsentrasi } \\
\text { spermatozoa x 10 }\end{array}$ \\
\hline Kontrol $(\mathrm{K})$ & 37,5 \\
Perlakuan 1 $\left(\mathrm{P}_{1}\right)$ & 38,8 \\
Perlakuan 1 $\left(\mathrm{P}_{2}\right)$ & 40,5 \\
\hline
\end{tabular}

\section{Motilitas Spermatozoa}

Didapatkan hasil rerata motilitas spermatozoa yang dibagi menjadi motilitas spermatozoa normal yaitu dan motilitas spermatozoa abnormal, dapat dilihat pada Tabel 2.

Tabel 2. Rerata Motilitas Spermatozoa

\begin{tabular}{ccc}
\hline Kelompok & $\begin{array}{c}\text { Motilitas } \\
\text { Normal (\%) }\end{array}$ & $\begin{array}{c}\text { Motilitas } \\
\text { Abnormal (\%) }\end{array}$ \\
\hline$(\mathrm{K})$ & 70 & 5 \\
$\left(\mathrm{P}_{1}\right)$ & 92 & 8 \\
$\left(\mathrm{P}_{2}\right)$ & 95 & 5 \\
\hline
\end{tabular}

Pada Tabel 2. dapat dilihat terjadi perubahan rerata motilitas spermatozoa antara kelompok kontrol (K), kelompok perlakuan $1\left(\mathrm{P}_{1}\right)$ dan kelompok perlakuan 2 $\left(\mathrm{P}_{2}\right)$. Diantara kelompok perlakuan, rerata motilitas kelompok perlakuan $2\left(\mathrm{P}_{2}\right)$ lebih tinggi daripada kelompok perlakuan $1\left(\mathrm{P}_{1}\right)$.

\section{Morfologi Spermatozoa}

Didapatkan hasil rerata morfologi spermatozoa yang dibagi menjadi morfologi spermatozoa normal dan morfologi spermatozoa abnormal, dapat dilihat pada Tabel 3.

Tabel 3. Rerata Morfologi Spermatozoa

\begin{tabular}{ccc}
\hline Kelompok & $\begin{array}{c}\text { Morfologi } \\
\text { Normal } \\
(\%)\end{array}$ & $\begin{array}{c}\text { Morfologi } \\
\text { Abnormal (\%) }\end{array}$ \\
\hline$(\mathrm{K})$ & 79 & 21 \\
$\left(\mathrm{P}_{1}\right)$ & 91 & 9 \\
$\left(\mathrm{P}_{2}\right)$ & 95 & 5 \\
\hline
\end{tabular}

Pada Tabel 3. dapat dilihat terjadi perubahan rerata morfologi spermatozoa antara kelompok kontrol (K), kelompok perlakuan $1\left(\mathrm{P}_{1}\right)$ dan kelompok perlakuan 2 $\left(\mathrm{P}_{2}\right)$. Diantara kelompok perlakuan, rerata morfologi kelompok perlakuan $2\left(\mathrm{P}_{2}\right)$ lebih tinggi daripada kelompok perlakuan $1\left(\mathrm{P}_{1}\right)$.

\section{Uji komparabilitas antara kelompok penelitian}

Berdasarkan hasil uji normalitas dan homogenitas data berdistribusi normal dan homogen, maka analisis komparatif yang digunakan adalah uji t-independent. Hasil analisis dapat dilihat pada Tabel 4. sampai Tabel 6

Tabel 4. Pengujian Rerata Kualitas Spermatozoa antara Kelompok Kontrol (K) dan Kelompok Perlakuan $1\left(\mathrm{P}_{1}\right)$

\begin{tabular}{lccc}
\hline $\begin{array}{c}\text { Kualitas } \\
\text { Spermatozoa }\end{array}$ & $\mathbf{( K )}$ & $\left.\mathbf{( P}_{\mathbf{1}}\right)$ & $\mathbf{P}$ \\
\hline Konsentrasi & 37,2 & 38,8 & 0,026 \\
Motilitas & 70 & 92 & 0,268 \\
Morfologi & 79 & 91 & 0,128 \\
\hline
\end{tabular}

Pada Tabel 4. dapat dilihat hasil uji komparabilitas kualitas spermatozoa antara kelompok kontrol (K) dan kelompok perlakuan $1\left(\mathrm{P}_{1}\right)$ yang menunjukkan adanya perbedaan rerata konsentrasi spermatozoa yang signifikan $(\mathrm{p}<0,05)$ antara kelompok kontrol (K) dan kelompok perlakuan $1\left(\mathrm{P}_{1}\right)$. Pada motilitas dan morfologi spermatozoa antara kelompok kontrol (K) dan kelompok perlakuan $1 \quad\left(\mathrm{P}_{1}\right)$ tidak menunjukkan perbedaan yang signifikan $(\mathrm{p}>0,05)$.

Tabel 5. Pengujian Rerata Kualitas Spermatozoa antara Kelompok Kontrol (K) dan Kelompok Perlakuan $2\left(\mathrm{P}_{2}\right)$

\begin{tabular}{lccc}
\hline $\begin{array}{c}\text { Kualitas } \\
\text { Spermatozoa }\end{array}$ & $\mathbf{( K )}$ & $\left.\mathbf{( P}_{\mathbf{2}}\right)$ & $\mathbf{P}$ \\
\hline Konsentrasi & 37,2 & 40,5 & 0,002 \\
Motilitas & 70 & 95 & 0,228 \\
Morfologi & 79 & 95 & 0,040 \\
\hline
\end{tabular}

Pada Tabel 5. dapat dilihat hasil uji komparabilitas kualitas spermatozoa antara kelompok kontrol (K) dan kelompok 
perlakuan $2\left(\mathrm{P}_{2}\right)$ yang menunjukkan adanya perbedaan rerata konsentrasi dan morfologi spermatozoa yang signifikan $(\mathrm{p}<0,05)$. Motilitas spermatozoa antara kelompok kontrol (K) dan kelompok perlakuan $2\left(\mathrm{P}_{2}\right)$ tidak menunjukkan perbedaan yang signifikan $(\mathrm{p}>0,05)$.

Tabel 6. Pengujian Rerata Kualitas Spermatozoa antara Kelompok Perlakuan $1\left(\mathrm{P}_{1}\right)$ dan Kelompok Perlakuan $2\left(\mathrm{P}_{2}\right)$

\begin{tabular}{lccc}
\hline $\begin{array}{c}\text { Kualitas } \\
\text { Spermatozoa }\end{array}$ & $\left.\mathbf{( P}_{\mathbf{1}}\right)$ & $\left.\mathbf{( P}_{\mathbf{2}}\right)$ & $\mathbf{P}$ \\
\hline Konsentrasi & 38,8 & 40,5 & 0,003 \\
Motilitas & 92 & 95 & 0,184 \\
Morfologi & 91 & 95 & 0,184 \\
\hline
\end{tabular}

Pada Tabel 6. dapat dilihat hasil uji komparabilitas kualitas spermatozoa antara kelompok perlakuan $1\left(\mathrm{P}_{1}\right)$ dan kelompok perlakuan $2 \quad\left(\mathrm{P}_{2}\right)$ yang menunjukkan perbedaan rerata konsentrasi spermatozoa yang signifikan $(\mathrm{p}<0,05)$. Motilitas dan morfologi spermatozoa antara kelompok kontrol $(\mathrm{K})$ dan kelompok perlakuan $2\left(\mathrm{P}_{2}\right)$ tidak menunjukkan perbedaan yang signifikan $\mathrm{p}=0,184(\mathrm{p}>0,05)$.

\section{BAHASAN}

Peningkatan konsentrasi dan morfologi spermatozoa tikus wistar yang dapat dilihat pada Tabel 1 dan Tabel 2. disebabkan karena isoflavon kedelai yang berperan sebagai antioksidan yang mempunyai kemampuan untuk mencegah peroksidasi lipid. Dalam keadaan normal, secara fisiologis sel memproduksi radikal bebas sebagai akibat dari reaksi biokimia dalam metabolisme sel aerob. ${ }^{9}$ Isoflavon kedelai mempunyai kemampuan sebagai antioksidan dan mencegah terjadinya kerusakan sel akibat radikal bebas melalui dua cara, yaitu dengan mendonorkan ion hidrogen dan bertindak sebagai scavenger radikal bebas secara langsung. ${ }^{9}$ Testis sebagai tempat berlangsungnya spermatogenesis bersifat rentan terhadap proses oksidasi oleh radikal bebas. Terdapatnya radikal bebas pada testis dapat mengubah kestabilan dan fungsi membran. $^{10}$

Motilitas spermatozoa tikus wistar menunjukkan adanya peningkatan, tetapi secara statistik setelah dianalisi dengan uji t-independent tidak ada perbedaan yang signifikan $(p>0,05)$. Peningkatan motilitas spermatozoa disebabkan karena kandungan isoflavon dan vitamin $\mathrm{E}$ dalam kacang kedelai yang berperan sebagai antioksidan. Vitamin E mampu mengendalikan peroksida lemak dengan menyumbangkan hidrogen ke dalam reaksi yang mampu mengubah radikal peroksil menjadi radikal tokoferol yang kurang reaktif, sehingga tidak mampu merusak rantai asam lemak dan melindungi sel dari kerusakan dan memperbaiki kualitas sperma. ${ }^{11}$ Mekanisme lain yang dapat meningkatkan motilitas spermatozoa mungkin dari asam amnio arginin yang terdapat dalam kedelai. Asam amino arginin dapat meningkatkan hormon testosteron dan berperan dalam proses spermatogenesis. ${ }^{12}$ Senyawa ini dapat memblok dan menahan agen yang menghambat glikolisis pada sel sperma, menyebabkan peningkatan aktivitas metabolik hingga mencapai delapan kali lipat. $^{12}$ Prosess ini akan meningkatkan ketersediaan energi sel sperma. ${ }^{11}$ Asam amino arginin mempunyai peranan penting dalam sistem pertahanan tubuh dan imunitas seluler. ${ }^{12}$ Penelitian lain menunjukkan bahwa pemberian asam amino arginin pada penderita oligospermia dan asthenospermia menunjukkan peningkatan kualitas sperma tanpa menimbulkan efek samping. ${ }^{12}$ Kekurangan asam amino arginin dapat mengacaukan metabolisme sperma sehingga mengakibatkan gangguan spermatogenesis.

Isoflavon merupakan komponen polifenol utama dalam kacang kedelai. ${ }^{13}$ Kandungan isoflavon dalam kedelai memiliki kemiripan struktur dengan estrogen, sehingga dapat berikatan dengan Receptor estrogen (RE) dan diduga sebagai senyawa antiandrogenik. Penelitian tentang isoflavon (genistein) sebagai senyawa antiandrogenik telah dilakukan oleh $\mathrm{Lee}^{14}$ menjelaskan bahwa pemberian genistein pada tikus masa pubertas dengan dosis 2,5 
mg/kgBB menyebabkan penurunan jumlah spermatozoa dalam testis dan epididimis serta terjadi hiperplasia sel leydig dan meningkatkan fibroblast interstisial dalam epididimis. Hal ini berbeda dengan hasil yang ditemukan oleh peneliti bahwa susu kacang kedelai dapat meningkatkan kualitas spermatozoa tikus wistar.

\section{SIMPULAN}

Berdasarkan hasil penelitian dapat disimpulkan bahwa pemberian susu kacang kedelai (Glycine max (L.) Merr.) dapat meningkatkan konsentrasi, motilitas, dan morfologi spermatozoa tikus wistar (Rattus norvegicus), sesuai dengan makin tinggi dosis susu kacang kedelai (Glycine max (L.) Merr.) yang diberikan.

\section{UCAPAN TERIMA KASIH}

Ucapan terima kasih disampaikan pada Dr. dr. Janette Rumbajan dan dr. Benny Wantouw MSc, Sp.And, dan pada semua pihak yang baik secara langsung maupun tidak langsung telah menumbuhkan ide atau gagasan dalam pemikiran penulis sehingga dapat menyelesaikan artikel ini.

\section{DAFTAR PUSTAKA}

1. Noviyanthi. Hubungan antara jumlah leukosit pada cairan semen dengan motilitas sperma pada pria pasangan infertil [Skripsi]. Sumatera: Universitas Sumatera Utara; 2013.

2. Sinaga ES. Pengaruh isoflavon kedelai terhadap jumlah kecepatan dan morfologi spermatozoa tikus putih jantan (Rattus Norvegicus) [Tesis]. Padang: Universitas Andalas; 2012.

3. Gultekin E, Yildiz F. Introduction to phytoestrogens. In: Yildiz F, editor. Phytoestrogens in functional foods. Boca Raton, Florida: CRC Press Taylor\&Francis Group LLC; 2006. p. 3-5.

4. Hermawanto HH, Hadiwidjaja DB. Analisis sperma pada infertilitas pria. Available from URL : http://www.tempo.co.id/medika/arsip/1 02002/pus- 3.htm. Akses 10 Oktober
2015.

5. Permatasari. Pengaruh pemberian ektrak kedelai dosis bertingkat terhadap jumlah spermatozoa mencit jantan strain balb/c [Skripsi]. Semarang: Universitas Diponegoro; 2007.

6. Wahyuni SR. Pengaruh isoflavon kedelai terhadap kadar hormon testosteron dan spermatogenesis tikus putih jantan (Rattus norvegicus) [Tesis]. Padang: Universitas Andalas; 2012.

7. Watanabe S. Systematic review of intervention studies using isoflavon suplement and proposal for further studies. In: Sugano M, editor. Soy in health and disease prevention. Boca Raton, Florida: CRC Press Taylor\&Francis Group LLC; 2006. p. 98.

8. Puspasari D. Pengaruh pemberian ekstrak kedelai dosis bertingkat terhadap morfologi spermatozoa mencit jantan strain Balb/C [Skripsi]. Semarang: Universitas Diponegoro; 2007.

9. Astutti S. Isoflavon kedelai dan potensinya sebagai penangkap radikal bebas. Jurnal Teknologi Industri dan Hasil Pertanian. 2008;13:126-32.

10. Mun'im, Abdul, Hanani, Endang. Fitoterapi dasar. Jakarta: Dian Rakyat; 2011. h. 237-39.

11. Nieschlag E, Behre HM. Andrology. Male Reproductive Health and Dysfunction. Second edition. Berlin; Heidelberg; New York; Barcelona; Hongkong; London; Milan; Paris; Singapore; Tokyo: Springer; 2000.

12. Saputri AA. Pengaruh pemberian ekstrak kedelai (Glycine max) terhadap motilits sperma mencit jantan [Skripsi].Semarang: Universitas Diponegoro; 2007.

13. Sartini M, Natsir DA, Dian P, Ismail. Ektraksi Isoflavon kedelai dan penentuan kadarnya secara Ultra Fast Liquid Chromatography (UFLC). Jurnal Sainsmat. 2014;3:130-31.

14. Lee BJ, Jeung EY, Yun YW, Kang JK, Baek IJ, Yon JM, et al. Effect exposure to genisten during pubertal developmental on the reproductive system of male mice. Journal reproductive developmental. 2004;50(4):399-409. 